\title{
ANÁLISE DISCURSIVA DA PERSONAGEM ISAURA, NA OBRA "A ESCRAVA ISAURA", DE BERNARDO GUIMARÃES
}

\author{
LOHANA LARISSA MARIANO CIVIERO ${ }^{1}$ \\ RENAN FABRÍCIO LORENZATTO DA SILVA
}

Programa de Pós-Graduação Stricto Sensu em Letras

Universidade Estadual do Oeste do Paraná - Campus Cascavel

Rua Universitária, 2069 - 85819-110 - Cascavel - PR - Brasil

lohanalarissa483@gmail.com, renanlorenzatto0610@gmail.com

\begin{abstract}
Resumo. Este artigo teve como principal objetivo fazer uma fusão entre Análise de Discurso e literatura, analisando os discursos sobre a personagem Isaura na obra "A Escrava Isaura", do autor Bernardo Guimarães. A partir das características de Isaura, analisamos aspectos sociais da personagem como protagonista e, além disso, estabelecemos possiveis relações interdiscursivas dos ditos da obra, dispondo sobre as condições de produção destes discursos produzidos no século XIX. A base teórica e metodológica desta pesquisa foi pautada nas considerações de Matos (1915), Mattoso (1990), Foucault (1987), Pêcheux (2008), Orlandi (2013) e Guimarães (1981). Ademais, a pesquisa mostrou singularidades do discurso da época de publicação do livro, de modo específico, sobre os ditos da sociedade acerca de Isaura.
\end{abstract}

Palavras-chave: A Escrava Isaura; literatura; Análise de Discurso.

\begin{abstract}
This article aims to make a merger between French Discourse Analysis and literature, analyzing the discourses about the character Isaura in the book "A Escrava Isaura", of Bernardo Guimarães. From Isaura's characteristics, was analyzed social aspects of her as leading figure and, moreover, was established possible interdiscursive relations of the discourse in book, relating about conditions of production of these XIX century discourse's. The theoretical and methodological basis of the work was Matos (1915), Mattoso (1990), Foucault (1987), Pêcheux (2008), Orlandi (2013) and Guimarães (1981). The research shows peculiarities in the discourse at the time of publication of the book with regard to the discourses of society in that time about Isaura.
\end{abstract}

Keywords: A Escrava Isaura; literature; Discourse Analysis.

\footnotetext{
${ }^{1}$ Bacharela em Comunicação Social com Habilitação em Jornalismo pela Univel. Mestre em Letras pela Unioeste. Acadêmica do curso de Letras - Português/Italiano da Unioeste.

${ }^{2}$ Bacharel em Comunicação Social com Habilitação em Jornalismo pela Univel. Mestre em Letras pela Unioeste. Acadêmico do curso de Letras - Português/Italiano da Unioeste.
} 


\section{INTRODUÇÃO}

A literatura brasileira, no período romântico, somente tomou forma quando o brasileiro entendeu que era mestiço, isso no sentido cultural e, também, antropológico. Desse modo, a partir da literatura, o brasileiro passou a fazer uma descrição de sua condição enquanto mestiço. Essa representação era feita de modo lírico, patético ou, até mesmo, de modo irônico. Além disso, por meio da literatura brasileira, os escritores encontravam um modo de expressar os pensamentos e, também, os sentimentos que perpassavam os indivíduos da sociedade. A partir disso ocorreu certa autonomia na literatura e no romantismo brasileiro. Destaca-se, nesse período romântico, a valorização dada pelos autores à sua própria cultura. Posteriormente a isto, veio o nacionalismo.

Segundo Candido (1999), o romantismo em 1830 teve novos aspectos: "[...] a poesia patriótica, o ensaio político, o sermão nacionalista" (CANDIDO, 1999, p. 36). E, durante esse período, as pessoas das letras tiveram grande influência ideológica na literatura e diversas críticas foram realizadas ao romantismo.

Bernardo Guimarães, um dos autores desse período, conseguiu mudar as perspectivas romancistas quando se colocou em posição de crítico. Guimarães publicou diversas opiniões em jornais, poemas, romances para a sociedade da época. Segundo Gomes (2010),

O pensamento crítico de Bernardo Guimarães, como veremos, defendia uma abordagem analítica impessoal que deveria nortear o público e os escritores a não cometerem os erros passados. Essa atividade deveria ser livre de amarras europeias conceituais e deveria desprender-se dos tons apologéticos vigentes (GOMES, 2010, p. 2).

Guimarães nasceu no dia 15 de agosto de 1825, na cidade de Ouro Preto, no estado de Minas Gerais. Foi também nessa cidade e no ano de 1884 que o autor faleceu. Bernardo Guimarães, além de romancista, foi um grande poeta, o qual o nome é frequentemente citado entre os grandes autores brasileiros de todos os tempos.

A obra de maior relevância do autor é "A Escrava Isaura”, publicada em 1875. O romance foi o livro que alavancou a carreira de Guimarães como escritor. A obra é conhecida por fazer diversas e severas críticas em relação à escravidão dos negros no Brasil. Além disso, é um marco na história da literatura brasileira, pois traz um personagem antiescravagista, libertário e, também, como descrito no livro, socialista, para ser o interesse romântico da protagonista. $O$ romance ainda excede na idealização romântica (de Isaura), a fim de conquistar a imaginação dos leitores perante as situações intoleráveis que aconteciam dentro e fora dos cativeiros dos escravos. O livro foi escrito antes da Lei Áurea (que só foi assinada em 1888), e tinha como objetivo abordar essas questões na sociedade em geral.

Visando aos estudos literários e, ainda, linguísticos acerca da Análise de Discurso de perspectiva francesa (doravante $\mathrm{AD}$ ), desenvolveremos análises a partir dos discursos sobre o corpo feminino de Isaura, ditos pelo seu dono e por Álvaro. Além desse aspecto, apresentaremos análises sobre o interesse romântico que Álvaro tem por Isaura na obra. Por meio desses discursos, produzidos e reproduzidos naquela época sobre a mulher e seu 
corpo, especificamente, sobre Isaura, analisaremos as condições de produção desses discursos, bem como, a formação discursiva.

\section{DESENVOLVIMENTO}

Um dos objetivos da análise literária é conseguir olhar para determinada obra literária com afinco, a fim de captar peculiaridades que não estão explícitas. Para que isso seja feito de modo apurado, é necessária atenção nos mínimos detalhes. Segundo Moisés (2007),

[...] a análise literária dispensa, em princípio, as achegas historiográficas, visto que objetiva, justamente, libertar o texto do peso morto dos preconceitos e das convenções ou das idéias passadas em julgado, a fim de redescobri-lo vivo, dinâmico, inesgotável e novo. No entanto, a realidade dos fatos mostra que, notadamente quando se trata do passado remoto, nenhum texto se deixa sondar em profundidade sem o auxílio da historiografia [...] o desmembramento de um texto põe a descoberto problemas e dúvidas que ele próprio nem sempre consegue resolver, simplesmente porque o texto (qualquer texto) remonta a uma ou mais tábuas de referência, cujo conhecimento se torna imperioso quando se pretende chegar aos sentidos ocultos na malha expressiva. Um escrito constitui sempre um ser vivo, empregando regras [...] (MOISÉS, 2007, p. 17).

Além disso, esta pesquisa busca uma nova perspectiva de estudo sobre um texto literário, ou seja, pretende estudar um texto literário por meio dos estudos linguísticos da AD. Desse modo, Mello (2005) discorre acerca dessa consonância:

Abordar o texto literário a partir de pontos de vista dos estudos da $\mathrm{AD}$ e tecer considerações sobre especificidades do texto literário pode parecer, para alguns, um despropósito. Entretanto, temos certeza que esses pontos de vista poderão nos ajudar a construir nosso raciocínio sobre a obra literária. Vemos que é possível tratar o texto literário buscando suas intenções, sua realidade, sua recepção, sua língua, sua história e seu valor a partir de sua estrutura comunicativa, enunciativa, discursiva... (MELLO, 2005, p. 39).

Assim, a $\mathrm{AD}$ nos dá a oportunidade de entender aspectos que vão além da trama textual da literatura. Poderemos entender as condições e a formação de dado discurso literário na obra "A Escrava Isaura".

Ponsoni (2011) tece sobre a aplicabilidade da teoria em um texto literário:

[...] a $\mathrm{AD}$, de sua parte, empenha-se em abrigar um quadro interpretativo em que sejam mobilizadas todas as vozes interdiscursivas a ecoar num dado objeto de análise - ela não faz isso somente no texto literário; ao contrário, ainda, atualmente, é um dos objetos de estudo que ela menos faz -, tirando da sombra, por meio de análises, os sentidos que sustentam e autorizam aquilo em que ela se debruça analiticamente (PONSONI, 2011, p. 56). 
A $\mathrm{AD}$ se consolidou na década de 60 constituindo assim um novo objeto de estudo, o discurso, que irá afetar o processo comum de conhecimento. Para esse estudo, a comunicação não é apenas uma transmissão ou troca de informações, ela vai além disso, pois o discurso envolve uma produção de sentidos, assim como, a construção histórica dos sujeitos que o falam.

Para Orlandi (2013),

São processos de identificação do sujeito, de argumentação, de subjetivação, de construção da realidade, etc. Por outro lado, tampouco assentamos esse esquema na ideia de comunicação. A linguagem serve para comunicar e para não comunicar. As relações de linguagem são relações de sujeitos e de sentidos e seus efeitos são múltiplos e variados. Daí a definição de discurso: o discurso é efeito de sentidos entre locutores (ORLANDI, 2013, p. 21).

Pêcheux (2008) afirma que o discurso é potencializado das construções sóciohistóricas do sujeito. A partir de sua identificação, o sujeito se constitui juntamente com um efeito social que estará em suas determinações inconscientes. De acordo com o autor,

[...] não há uma identificação plenamente bem sucedida, isto é, ligação sócio histórica que não seja afetada, de uma maneira ou de outra, por uma "infelicidade" no sentido performativo do termo - isto é, no caso, por um "erro de pessoa", isto é, sobre o outro, objeto de identificação (PÊCHEUX, 2008, p. 56).

A AD busca também compreensão da língua fazendo sentido, no que diz respeito ao âmbito simbólico do sujeito, sendo a língua parte da construção do homem e da história dele. Desse modo, o sujeito tem a capacidade de significar e de significar a si. O discurso é capaz de transformar esse sujeito e a sua realidade de convivência. Além disso, o sujeito só existe com a ideologia, pois a língua apenas significa quando há um sujeito com uma ideologia que a use. Segundo Orlandi (2013), "Consequentemente, o discurso é o lugar em que se pode observar essa relação entre língua e ideologia, compreendendo-se como a língua produz sentidos por/para os sujeitos" (ORLANDI, 2013, p. 17).

De acordo com Versa (2017),

A literatura, pensada como um texto subjetivo, de composição intencional, como entende a pragmática, não poderia ser um objeto cabível à $\mathrm{AD}$. Contudo, quando falamos em discurso literário, podemos pensá-lo sob determinadas condições de produção. Ademais, há aquilo que foge dessa intenção do autor, os efeitos de sentido, o inconsciente que fala através da literatura (VERSA, 2017, p.17).

Para Fernandes (2009) apud Versa (2017), a AD ocasionalmente utiliza o texto literário como campo de estudo dos personagens visando-os discursivamente como sujeitos. "[...] mesmo em produções literárias que trazem marcas de passionalidade, ou versam sobre sentimentalismo, a subjetividade é histórica e exteriormente modificada" (FERNANDES, 2009, apud VERSA, 2017, p.13). 
Em Guimarães (1981), o sujeito Isaura é retratado como uma mulher muito bela que é também filha da escrava mulata Juliana e de um homem branco. Devido à miscigenação de raças, Isaura não puxou os traços negros de sua mãe. Porém, do mesmo modo, é tratada como uma escrava perante a sociedade, por ter o sangue de uma negra. Por outro lado, por ter a pele branca, Isaura não teve a mesma vida de uma escrava retinta ${ }^{3}$. Assim, a moça cresceu na casa grande e foi criada pelo casal de senhores.

Além disso, Isaura teve a oportunidade de estudar igual as mulheres brancas que tinham melhores condições financeiras. Ela aprendeu a cantar e, também, todos os trejeitos da sociedade rica da época. Com isso, tornou-se a típica moça de família. $\mathrm{O}$ personagem Álvaro, já citado anteriormente como o interesse romântico de Isaura, a descreve como a perfeição em forma de mulher. Essa característica é muito presente em várias obras do romantismo.

Vejamos Sequências Discursivas (doravante SD) de como Guimarães (1981) descreve Isaura:

SD1: Logo à direita do corredor encontramos aberta uma larga porta, que dá entrada à sala de recepção, vasta e luxuosamente mobiliada.

SD2: Acha-se ali sozinha e sentada ao piano uma bela e nobre figura de moça.

SD3: As linhas do perfil desenham-se distintamente entre o ébano da caixa do piano, e as bastas madeiras ainda mais negras que ele.

SD4: São tão puras e suaves essas linhas, que fascinam os olhos, enlevam a mente, e paralisam toda análise". (GUIMARÃES, 1981, p. 11)

Logo na SD1, o lugar onde está Isaura é colocado em evidência. É chamativo o modo com que Guimarães descreve o espaço: "larga porta, que dá entrada à sala de recepção, vasta e luxuosamente mobiliada", em outras palavras, um lugar que Isaura não estaria se fosse uma escrava como as outras. A sala é descrita como superior, pertencente aos senhores brancos, e a beleza da sala, tão contemplada, tão luxuosa, é seguida da beleza de Isaura nas linhas seguintes.

Na SD2, já conseguimos sentir a presença de Isaura nos discursos do narrador "nobre figura de moça". Isaura é o ser mais lindo que seus olhos já tiveram o prazer de ver. O sujeito Isaura tem a beleza comparada à da sala em que está presente, assim, essa beleza é "disponível" para os olhos da elite, pois são os ricos que sabem apreciar as artes, as riquezas e uma boa música. Esse último aspecto é citado por meio do piano. $\mathrm{O}$ visual de Isaura em si combina com tudo o que é descrito.

As SD3 e SD4 seguem com o narrador comparando a beleza de Isaura com o piano: ora com a madeira do instrumento, ora com cor. Além disso, o narrador frisa que o piano perde seu brilho quando Isaura está perto dele. A moça e o instrumento são perfeitos e harmônicos. Então o narrador discorre que a personagem é um ser lindo e que nunca foi visto. A beleza é identificada como pura, que fascina os olhos das pessoas. De acordo com o narrador, Isaura é perfeita. Todo e qualquer acontecimento perderia sentido

${ }^{3}$ De pele mais escura. 
perto da personagem, uma vez que ela é tão linda esteticamente, que não é possível se atentar a mais nada após isso.

Essas SD são discursos reproduzidos pelo narrador da obra, a qual tem como escritor Guimarães. É possível notar que o aspecto ideológico social do autor atravessa o discurso, uma vez que o autor utiliza o seu lugar de escritor para reproduzir inconscientemente suas ideologias a respeito de uma escrava, por exemplo.

A seguir temos duas SD nas quais a beleza de Isaura encontra-se em evidência:

SD5: A tez é como o marfim do teclado, alva que não deslumbra, embaçada por uma nuance delicada, que não sabereis dizer se é leve palidez ou cor-de-rosa desmaiada. [...]

SD6: O colo donoso e do mais puro lavor sustenta com graça inefável o busto maravilhoso. Os cabelos soltos e fortemente ondulados se despenham caracolando pelos ombros em espessos e luzidios rolos, e como franjas negras escondiam quase completamente o dorso da cadeira, a que se achava recostada (GUIMARÃES, 1981, p. 11).

É importante frisar que as obras do período romântico tinham como característica a descrição dos detalhes, especialmente, por meio dos adjetivos. Além disso, essas obras visavam mostrar a mulher em sua totalidade por meio da beleza, da perfeição de seu corpo e do amor. Observa-se esses aspectos na SD5, que descreve a beleza de Isaura por meio de adjetivos ligados à beleza do marfim do teclado, retomando mais uma vez a ideia de perfeito como um instrumento musical. Aqui notamos quase que o conceito do belo universal, que é algo inalcançável.

A SD6 continua com a romantização em torno do sujeito Isaura, o ser perfeito. "O colo donoso e do mais puro lavor sustenta com graça inefável o busto maravilhoso" nesse trecho, o sujeito Isaura é quase que colocado como um ser sexual, pois o elogio está entre a linha tênue elogio e desejo.

Esse aspecto está intrinsecamente relacionado com o sentido da mulher idealizada, a mulher que é o ser mais bonito e que, às vezes, era tratada com certo amor doentio. Tal sentimento, já trabalhado em diversas obras, é o de obsessão, de posse por parte dos personagens homens em relação às mulheres. O narrador expõe essa característica por meio de Leôncio que possuía um amor doentio por Isaura.

LEÔNCIO impaciente e com o coração ardendo nas chamas de uma paixão febril e delirante não podia resignar-se a adiar por mais tempo a satisfação de seus libidinosos desejos. Vagando daqui para ali por toda a casa, como quem dava ordens para reformar o serviço doméstico, que daí em diante ia correr todo por sua conta, não fazia mais do que espreitar todos os movimentos de Isaura, procurando ocasião de achála a sós para insistir de novo e com mais força em suas abomináveis pretensões (GUIMARÃES, 1981, p. 50).

A partir disso, apresentamos o conceito de formação discursiva, que é quando as posições ideológicas do sujeito são colocadas no social a partir das palavras que são produzidas, ou seja, o sentido das palavras será dado de acordo com as ideologias do sujeito que o reproduz. "As formações discursivas, por sua vez, representam nos discursos 
as formações ideológicas. Desse modo, os sentidos sempre são determinados ideologicamente. Não há sentido que não o seja" (ORLANDI, 2013, p. 43).

Com base nessa definição, podemos relacionar as diferenças nos sentidos dado à personagem Isaura em "A Escrava Isaura". Na obra, o personagem Leôncio, dono de Isaura, a via como a mulher que serviria para ser usada pelos homens (assim como as negras escravas que, naqueles tempos, eram diariamente estupradas por seus donos sem qualquer consequência). Para Leôncio, Isaura deveria ser dele; além de escrava, ela deveria servi-lo e manter relações sexuais com ele. Isaura, mesmo sendo branca, tinha que estar pronta para o próprio desfrute de Leôncio, afinal suas raízes eram negras.

Além disso, esse personagem também vê Isaura como um ser perfeito e, de modo explícito, Leôncio é retratado como se sofresse de um amor doentio, de algo que ele não conseguiria manter o controle até alcançar o objetivo. Porém, Isaura sempre tenta com que ele fique o mais longe possível, recusando as suas investidas. Leôncio fica então bravo com a rejeição e ameaça a moça, conforme a próxima SD:

SD7: - Isaura, - disse Leôncio com voz áspera apontando para os instrumentos de suplício, - eis ali o que te espera, se persistes em teu louco emperramento. Nada mais tenho a dizer-te; deixo-te entre o meu amor e meu ódio. Qualquer dos dois, tu bens sabes, são violentos e poderosos. Adeus!... (GUIMARÃES, 1981, p. 54).

Observa-se, principalmente, o comportamento doentio que Leôncio tem com Isaura. Guimarães coloca os discursos de Leôncio sempre com um teor de insatisfação; como se o personagem nunca estivesse completamente feliz com suas conquistas. Leôncio acredita que Isaura só tem duas opções: o seu amor ou o seu ódio. De acordo com o personagem, em qualquer um dos casos será violento e poderoso. Como justificativa comportamental, Leôncio é descrito como alguém totalmente mau e sem caráter. O personagem é dependente de Isaura (romanticamente e sexualmente) e "luta", em diversos trechos da obra, buscando esse falso amor que não é correspondido pela protagonista. Assim, o sentimento de Leôncio para com a protagonista não é algo saudável e pode ser lido como mais uma bonificação, um prêmio, pois Isaura é disputada por diversos homens, em vários lugares que ela aparece, e não como um amor verdadeiro que o antagonista poderia sentir.

Por outro lado, quando Isaura conhece Álvaro, advogado abolicionista, esse a vê como um ser totalmente idealizado e perfeito. Mas, diferentemente de Leôncio, para Álvaro a beleza de Isaura extrapola o físico e vai além da alma. Para o advogado, tudo em Isaura é perfeito e digno do mais puro amor dele. Além disso, o moço faz de tudo para protegê-la.

Vejamos uma SD em que Álvaro diz que vai lutar por Isaura:

SD8: - Por piedade, Isaura, não me martirizes mais com essa maldita palavra, que constantemente tens nos lábios. Escrava tu!... Não o és, nunca o fostes, e nunca o será. Pode acaso a tirania de um homem ou da sociedade inteira transformar em um ente vil, e voltar à escravidão aquela que das mãos de Deus saiu um anjo digno do respeito e adoração de todos? Não, Isaura; eu saberei erguer-te ao nobre e um roso lugar a 
que o céu te destinou, e conto com a proteção de um Deus justo, porque protejo um dos seus anjos (GUIMARÃES, 1981, p. 102).

Observa-se o quanto Álvaro não enxerga Isaura como escrava, não distinguindo nada entre os dois. Para o personagem, Isaura é somente o amor de sua vida e nada mais, o que difere ele dos outros sujeitos da trama. É possível observar que o personagem Álvaro também está obcecado por Isaura. Por outro lado, essa obsessão seria saudável quando comparada a de Leôncio, pois esse personagem romantiza e pensa em um futuro com Isaura. Álvaro não estabelece, de modo explícito, uma relação de poder entre homem e mulher como faz o antagonista.

Assim, podemos então estabelecer relações com o significante do nome Isaura entre os dois sujeitos - Leôncio e Álvaro. Cada um deles tem em seu discurso e sua atitude formações ideológicas que o atravessam. O primeiro, por exemplo, pertence a uma ideologia escravocrata e o outro antiescravista.

Pontuamos ainda que os discursos do personagem Álvaro são os mesmos do narrador do romance, conforme as primeiras SD. Talvez tais aspectos possam ser caracterizados pelo próprio Bernardo Guimarães, visto que ele também era contra a escravidão. Percebe-se que o discurso de Álvaro e do narrador é escrito similarmente no que diz respeito à imagem e à pessoa de Isaura. Vejamos alguns exemplos no próprio corpus.

\begin{abstract}
SD9: Assim o cumpriu com mais religioso escrúpulo. À medida que a menina foi crescendo e entrando em idade de aprender, foi-lhe ela mesma ensinando a ler e escrever, a coser e a rezar. Mais tarde procurou-lhe também mestres de música, de dança, de italiano, de francês, de desenho, comprou-lhe livros, e empenhou-se enfim em dar à menina a mais esmerada e fina educação, como o faria para com uma filha querida. (GUIMARÃES, 1981, p. 17).
\end{abstract}

$\mathrm{Na}$ SD9, além da beleza de Isaura, procurou-se tratar a jovem menina como se ela não fosse escrava. Após a morte de sua mãe (a escrava Juliana), Isaura foi levada até a casa grande, onde foi tratada como uma filha pelo casal. Lá, a jovem recebeu do melhor que tinha na época. A falta de traços negros em seu corpo foi o ponto máximo de Isaura conseguir ser tratada de forma diferente dos seus demais. Porém, quando Isaura está mais crescida e começa a receber elogios dos homens da sociedade, Leôncio mostra sua verdadeira face em relação ao seu sentimento para com a moça.

SD10: - Ah! Isaura, Isaura! ... tem cuidado. Se até aqui tenho sofrido com paciência as tuas repulsas e desdéns, não estou disposto a suportar, que em minha casa, e quase em minha presença, estejas a escutar galanteios de quem quer que seja, e muito menos revelar o que aqui se passa. Se não queres o meu amor, evita ao menos de incorrer no meu ódio.

SD11:- Perdão, senhor, que culpa tenho eu de andarem a perseguir-me? - Tens alguma razão; estou vendo, que me verei forçado a desterrar-te desta casa, e a esconder-te em algum canto, onde não sejas vista e cobiçada...

- Para que, senhor... 
- Basta; não posso te ouvir agora, Isaura. Não convém que nos encontrem aqui conversando a sós. Em outra ocasião te escutarei. (GUIMARÃES, 1981, p. 25).

Ambas SD são diálogos entre Isaura e Leôncio. Na SD10, observa-se o comportamento doentio de Leôncio ao cobiçar Isaura e ao se fazer de vítima em relação a esse amor não correspondido. Para ele, o amor que a moça não corresponde é o que o faz sofrer e ter ódio. Aqui, retoma-se a ideia de que Isaura seria apenas um prêmio, e não alguém para compartilhar a vida, como pensa Álvaro. Vemos também que Leôncio não está disposto a perder, uma vez que diz "Se não queres o meu amor, evita ao menos de incorrer no meu ódio". Para o personagem, o simples fato de Isaura existir e resistir a esse amor dele, já é um sinal de que ele precisa odiar, pois a moça tem apenas a opção de ficar com ele.

Esse discurso de Leôncio ecoa discursos reproduzidos atualmente, por exemplo, é muito comum a frase, "Não quer ficar comigo, não vai ficar com mais ninguém", a qual um sujeito, geralmente homem, profere à sua parceira, em situações em que o relacionamento não está mais funcionando. Na maioria desses discursos, o homem frisa seu poder e deixa claro à mulher que ela tem que permanecer naquele relacionamento ou não poderá ter mais nada com ninguém, resultando, assim, em uma possível morte dessa mulher. Podemos relacionar essa situação com a SD10, em que Leôncio discursa sobre o ódio. Ademais, esse personagem demonstra ser um sujeito abusivo, que não mede esforços para conseguir o que quer.

$\mathrm{Na}$ SD11, novamente temos um diálogo entre Isaura e Leôncio. Nesse, Isaura questiona que não é culpada por ser perseguida por Leôncio. $\mathrm{O}$ antagonista responde que já que o relacionamento com a moça não irá acontecer, o melhor seria que ele se forçasse a isolar Isaura na casa e escondê-la, para que ninguém, nenhum outro sujeito homem, pudesse vê-la. A SD termina com mais uma vitimização de Leôncio, "Basta; não posso te ouvir agora, Isaura", a qual o mesmo aponta que seria errado se alguém os visse ali, juntos, naquela conversa. É possível perceber uma relação de poder entre Leôncio e Isaura. Primeiramente, por ela ser mulher e ele homem, e, também, por ele ter um status social muito acima que ela. Leôncio em seu discurso demonstra o seu poder e coage a moça submissa até ao ponto de ela lhe pedir perdão.

Na próxima citação, Guimarães (1981) descreve Isaura mais uma vez, agora sob o olhar do personagem Álvaro:

Uma vez sentada ao piano, logo que seus dedos mimosos e flexíveis, pousando sobre o teclado, preludiaram alguns singelos acordes, a moça sentiu-se outra, revelando aos circunstantes maravilhados um novo e original aspecto de sua formosura. A fisionomia, cuja expressão habitual era toda modéstia, ingenuidade e candura, animou-se de luz insólita; o busto admiravelmente cinzelado, ergueu-se altaneiro e majestoso; os olhos extáticos, alcançaram de ofegar, túrgidos e agitados, como oceano escapelado; seu colo distendeu-se alvo e esbelto como o do cisne, que se apresenta a desprender os divinais gorjeios (GUIMARÃES, 1981, p. 67).

Vemos que Álvaro descreve Isaura enquanto a mesma toca piano. Bem como o narrador da obra, o moço discorre sobre Isaura de modo sincero e puro, utilizando muitos 
adjetivos positivos para a moça. Com isso, podemos perceber que há distinções no sentido do nome "Isaura" e como a mesma é tratada, ora pelo narrador e por Álvaro que gostam, possuem certo afeto por Isaura, ora por Leôncio que somente vê a moça como algo perfeito e inalcançável e, por isso, a trata mal sempre que possível. Essas diferenças acontecem por conta das formações discursivas que o Álvaro, o narrador e o Leôncio estão postos, as quais a ideologia está atrelada aos sentidos.

Desse modo, Álvaro e o narrador estão em uma formação ideológica antiescravista, o que faz com que seus discursos reproduzam aspectos nesse sentido. Já Leôncio está relacionado a uma ideologia escravista, que representa todo o discurso negativo, abusivo do personagem sobre Isaura. Assim, tais discursos estão ligados à dada formação ideológica e determinados por meio dos sentidos. Ressaltamos também que o nome próprio "Isaura", que na obra está relacionado à escrava branca, tem sentidos distintos a depender de quem o diz. Segundo Orlandi (2013), "Palavras iguais podem significar diferentemente porque se inscrevem em formações discursivas diferentes" (ORLANDI, 2013, p. 44).

Todas as situações vivenciadas pela escrava Isaura, anteriores a sua fuga, são por conta da posição-sujeito que ela estava inserida. Isso, considerando que essa posiçãosujeito da personagem é atravessada por interdiscursos sociais e históricos de gênero, de raça e de identidade. Esse interdiscurso é "[...] todo o conjunto de formulações feitas e já esquecidas que determinam o que dizemos" (ORLANDI, 2013, p. 3).

Considerando o interdiscurso e a forma como a língua é atravessada pela história e pela ideologia, materializando questões mais complexas como o preconceito racial a partir do discurso, torna-se importante retomar Pêcheux (2008) que afirma:

O objeto da linguística (o próprio da língua) aparece assim atravessado por uma divisão discursiva entre dois espaços: o da manipulação de significações estabilizadas, normatizadas por uma higiene pedagógica do pensamento, e o de transformações do sentido, escapando a qualquer norma estabelecida a priori, de um trabalho do sentido sobre o sentido, tomados no relançar indefinido das interpretações (PÊCHEUX, 2008, p. 51).

Nessa perspectiva, ainda é importante frisar que, de acordo com Orlandi (2013),

[...] o sentido não existe em si mas é determinado pelas posições ideológicas colocadas em jogo no processo sócio-histórico em que as palavras são produzidas. As palavras mudam de sentido segundo as posições daquelas que as empregam. Elas "tiram" seu sentido dessas posições, isto é, em relação às formações ideológicas nas quais essas posições se inscrevem (ORLANDI, 2013, p. 42).

Desse modo, a partir de interdiscursos, juntamente com a formação discursiva, os ditos da sociedade daquela época sobre, principalmente, servidão, foram fundamentais para a formação discursiva de Leôncio, bem como, dos outros homens da obra, uma vez que tal formação discursiva era baseada em uma ideologia vigente da época, que tratava a escravidão como algo natural, normal e, ainda, necessário. Ressaltamos que a escravidão aqui era exclusiva ao povo negro. 
A etnia negra e também o corpo negro, principalmente, no período escravocrata, têm papéis na sociedade patriarcal. Para Mattoso (1990), os escravos viviam em um sistema muito estruturado de controle e dominação, no qual se adaptavam às necessidades de exploração de seu corpo para o trabalho agrícola. Segundo a autora,

À primeira vista, o seu modelo é o de uma sociedade dicotômica de senhores e escravos, dominantes e dominados, brancos e negros. Nesse sistema patriarcal, o controle absoluto de exploração parece estar entre as mãos dos proprietários do patrimônio, isto é, da terra e sobretudo dos instrumentos da produção: esses são os escravos com seus braços, o engenho de açúcar com suas máquinas (MATTOSO, 1990, p. 108).

As mulheres negras também utilizavam seus corpos para o trabalho na lavoura e, além disso, como citamos anteriormente, elas eram exploradas sexualmente a fim de proporcionar prazer aos seus senhores. Ademais, algumas mulheres negras eram as "mães de leite" dos filhos dos fazendeiros, satisfazendo ainda uma necessidade dos brancos.

Isaura, também vítima do sistema escravocrata por herança genética de sua mãe, era propriedade de seu dono Leôncio que tinha uma relação extremamente obsessiva e abusiva com ela. A moça era submetida a diversos abusos por parte de seu dono, por exemplo, em diversos trechos da obra percebe-se tons de ironia ou sarcasmo nos discursos de Leôncio para com Isaura. Após diversas discussões que vinham acontecendo no decorrer da trama, de modo específico, no capítulo IX, observa-se explicitamente esta relação:

SD12: A tão severa e esmagadora exprobração, Leôncio sentiu revoltarse o seu orgulho.

- Cala-te, escrava insolente! - bradou cheio de cólera. - Que eu suporte sem irritar-me os teus desdéns e repulsas, ainda vá: mas repreensões! ... com quem pensas que tu falas? ...

- Perdão! Senhor! ... exclamou Isaura aterrada e arrependida das palavras, que the tinham escapado (GUIMARÃES, 1981, p. 52).

Como já dito, para Leôncio não existe a opção de perder Isaura para outro homem. Assim, a morte pode acontecer, afinal é impensável outra pessoa ficar com a moça. Na SD12, percebemos mais uma vez o comportamento abusivo com Isaura, em que o personagem retoma, inclusive, o fato de Isaura ser escrava "Cala-te, escrava insolente" (gritando com raiva). Essa SD segue com a vitimização do personagem, em que o mesmo se coloca como o real sofredor de tudo isso "Que eu suporte sem irritar-me os teus desdéns e repulsas", retomando mais uma vez o fato de que Isaura não corresponde o grande amor que ele teria por ela.

Isaura responde com desculpas, o que remete à submissão da moça ao homem, principalmente, porque ela ainda é propriedade de Leôncio, por ser escrava. São vários os trechos em que Isaura e Leôncio discutem, situações que sempre são iniciadas por Leôncio. A moça, a todo o momento, é colocada como inferior e submissa a seu dono, posição muito comum na época escravagista. A discussão entre Isaura e Leôncio vai piorando ao longo das linhas que vão estruturando esse dado capítulo. O personagem vai ficando cada vez mais ácido com suas palavras, carregando ódio em suas ações. A 
posição-sujeito de Isaura é de completa submissão e sofrimento por não querer ceder aos caprichos de Leôncio:

- Ah! meu senhor, por piedade! - exclamou Isaura, caindo de joelhos aos pés de Leôncio, e levantando as mãos ao céu em contorções de angústia; pelas cinzas ainda quentes de seu pai, há poucos dias falecido, pela alma de sua mãe, que tanto lhe queria, não martirize a sua infeliz escrava. Acabrunhe-me de trabalhos, condene-me ao serviço o mais grosseiro e pesado, que a tudo me sujeitarei sem murmurar; mas o que o senhor exige de mim, não posso, não devo fazê-lo, embora deva morrer (GUIMARÃES, 1981, p. 53).

No discurso de Isaura fica evidente o uso de seu corpo para o trabalho, não muito diferente daquele que Mattoso (1990) retrata anteriormente. Segundo Foucault (1987), o corpo está ligado diretamente ao campo político, uma vez que as relações sociais de poder estão relacionadas com ele.

Este investimento político do corpo está ligado, segundo relações complexas e recíprocas, à sua utilização econômica; é, numa boa proporção, como força de produção que o corpo é investido por relações de poder e de dominação; mas em compensação sua constituição como força de trabalho só é possível se ele está preso num sistema de sujeição (onde a necessidade é também um instrumento político cuidadosamente organizado, calculado e utilizado); o corpo só se torna força útil se é ao mesmo tempo corpo produtivo e corpo submisso (FOUCAULT, 1987, p. 29).

De acordo com Orlandi (2013), “A paráfrase representa assim o retorno aos mesmos espaços do dizer. Produzem-se diferentes formulações do mesmo dizer sedimentado" (ORLANDI, 2013, p. 36). Podemos também relacionar esse fenômeno com o nosso corpus de análise. A paráfrase fica evidente, principalmente, nos momentos em que Isaura, antes tratada como branca mesmo sendo filha de uma escrava, começa a sofrer as violências que os escravos sofriam em suas vidas.

Além da violência psicológica, que Isaura vai conhecendo aos poucos em sua vida nos momentos em que Leôncio faz ameaças a moça, ela sofre também da violência física, chegando a ir ao tronco. É nesse momento que fica explícito o tamanho a violência e, também, o "retorno aos mesmos espaços de dizer", pois já estava dito que os escravos iriam ao tronco caso fizessem algo que é considerado errado por seus donos. Ao acionar o sentido de escrava, por meio de sua mãe, Isaura repetiu aqueles dizeres escravocratas.

\section{CONCLUSÕES}

As análises realizadas revelam a exemplificação de como os discursos sobre a personagem Isaura se formaram. Isso está diretamente relacionado com o meio em que os sujeitos estavam inseridos em todo processo da narrativa e, não necessariamente, com a época em que se encontravam, pois é sabido que os negros eram tratados de formas terríveis, totalmente marginalizados. Além disso, eram usados apenas como instrumentos de trabalho escravo naquela época. Esse aspecto é nítido quando analisamos os discursos de Leôncio e Álvaro sobre Isaura. 
A obra traz um olhar diferenciado de alguns personagens naquela época para com os negros, como exemplo, o personagem Álvaro. Muito dessa característica vem das formações ideológicas do próprio autor do romance, Bernardo Guimarães, que era contra o escravagismo. O autor, por meio dos personagens e, também, do narrador, mostra um outro sentido aos negros, tentado assim mudar a realidade com seus escritos.

A personagem Isaura é descrita em diversos momentos como um dos seres mais lindos que já passaram pela Terra; sempre com elogios e adjetivos ligados à natureza e o que há de melhor no mundo. Percebemos e apontamos como esse movimento de elogio é demonstrado pelos personagens Álvaro e Leôncio de maneiras diferentes e por motivos distintos. Para Álvaro, interesse romântico de Isaura, elogiar e romantizar a protagonista é algo que está além dele; a beleza da moça é divina. Por outro lado, Leôncio tece elogios à Isaura, mas com intenções sexuais, para saciar um desejo. Para o antagonista, Isaura está mais como um prêmio, uma conquista do que um amor romântico. E, embora a personagem seja dele, no que diz respeito ao pertencimento por ser escrava, Leôncio precisa de Isaura, pois acredita que só assim conseguirá tudo que almeja.

Os discursos sobre Isaura mesclam-se durante a obra, uma vez que são ditos ora por Álvaro e ora por Leôncio. É possível observar nitidamente a diferença entre os dois, ainda que ambos endeusem Isaura querendo seu amor. $\mathrm{O}$ que se distingue são as formas com que os personagens masculinos buscam esse sentimento, e como isso afeta o modo com que Isaura é tratada por esses dois a depender da aceitação ou não da moça.

Tanto Álvaro quanto Leôncio pertencem a formações discursivas que são opostas ideologicamente. Um é dono de escravos, o outro é abolicionista. Isso reflete nos sentidos postos em seus discursos para e sobre Isaura. Enquanto um quer Isaura para completar sua vida romanticamente e tratá-la quase que como um ser espiritual, o outro quer a personagem como simples prêmio.

\section{REFERÊNCIAS}

CANDIDO, Antonio. Iniciação à literatura brasileira: resumo para principiantes. 3 ed. São Paulo: Humanitas, 1999.

FOUCAULT, Michel. Vigiar e punir: nascimento da prisão. Tradução de: Raquel Ramalhete. 20 ed. Petrópolis: Vozes, 1987.

GOMES, Ednaldo Cândido Moreira. Bernardo Guimarães, o crítico. Darandina Revista Eletrônica, Juiz de Fora, v. 02, n. 02, dez/2010. Disponível em: $<$ http://www.ufjf.br/darandina/files/2010/01/Ednaldo-C\%C3\%A2ndido-Moreira-

Gomes.pdf>. Acesso em: 29 set. 2018.

GUIMARÃES, Bernardo. A escrava Isaura. 10 ed. São Paulo: Ática, 1981.

MATTOSO, Kátia M. de Queirós. Ser escravo no Brasil. Tradução de: James Amado. 3 ed. São Paulo: Brasiliense, 1990.

MELLO, Renato de. Análise de discurso \& literatura: uma interface real. In:

(Org.). Análise do discurso \& literatura. Belo Horizonte: Núcleo de Análise do Discurso, 2005.

MOISÉS, Massaud. A análise literária. São Paulo: Cutrix, 2007. 
ORLANDI, Eni Puccinelli. Análise de discurso: princípios e procedimentos. 11 ed. Campinas: Pontes, 2013.

PÊCHEUX, Michel. O discurso: estrutura ou acontecimento. Tradução: Eni Puccinelli Orlandi. 5 ed. Campinas: Pontes, 2008.

PONSONI, Samuel. Análise discursiva da literatura como dispositivo enunciativo: 0 caso de Cadeiras Proibidas. Dissertação (Mestrado em Linguística) - Centro de Educação e Ciências Humanas, Universidade Federal de São Carlos. São Carlos, p. 145. 2011.

PICCHIO, Luciana Stegagno. Literatura brasileira: das origens a 1945. São Paulo: Martins Fontes, 1988. Tradução: Antonio de Padua Danesi.

VERSA, Cezar. Duas sendas do discurso psicótico em $O$ dia em que matei meu pai: esse silêncio... você ainda está aí? Tese (Doutorado em Letras) - Programa de PósGraduação Stricto Senso em Letras, Universidade Estadual do Oeste do Paraná. Cascavel, p. 92.2017.

Artigo recebido em: set. de 2019.

Aprovado e revisado em: mar. de 2020.

Publicado em: julho de 2020.

Para citar este texto:

CIVIERO, Lohana Larissa Mariano.; SILVA, Renan Fabrício Lorenzatto da. Análise Discursiva da Personagem Isaura, na obra "A Escrava Isaura", de Bernardo Guimarães. Entremeios [Revista de Estudos do Discurso, ISSN 2179-3514, on-line, www.entremeios.inf.br], Seção Estudos, Programa de Pós-Graduação em Ciências da Linguagem (PPGCL), Universidade do Vale do Sapucaí (UNIVÁS), Pouso Alegre (MG), vol. 21, p. 67-80, jan. - jun. 2020.

DOI: http://dx.doi.org/10.20337/ISSN2179-3514revistaENTREMEIOSvol21pagina67a80 